\title{
JURNAL ILMIAH TEKNIK INDUSTRI
}

ISSN: $1412-6869$ (Print), ISSN: 2460-4038 (Online) Journal homepage: http://journals.ums.ac.id/index.php/iiti/index doi:10.23917/jiti.v20i1.13920

\section{Marketing Development Model of Goyor Woven Fabric Increases Consumer Buying Interest in Pandemic Covid-19 Era: Study at Sragen Goyor Industry Center}

\author{
Suranto ${ }^{1 \mathrm{a}}$, Much. Djunaidi ${ }^{1 \mathrm{~b}}$
}

\begin{abstract}
Goyor woven fabric is a product of the creative industry, a micro, small and medium enterprises (SMEs) product in weaving. Goyor woven fabric is developed industrial center locations at Kalijambe, Miri, Plupuh, Sragen. Goyor woven fabric, as a result of weaving craft, is a handmade woven fabric through a non-machine loom (ATBM). The study aims to raise the potential of woven fabric products so that woven fabric products (goyor) become attractive to consumers and increase consumer buying interest. The strategy applied to increase sales volume and increase consumer buying interest is through marketing models by marketing mix approaches $\mathrm{GP}$ (products, prices, promotions, distribution, people, physic, process, public relation, and power) to consumer buying interest. This research is beneficial as a marketing development model of market-oriented goyor Woven Fabric. The research objectives are to (a) analyze woven fabric goyor products based preferred by consumers; (b) analyze the marketoriented fabric goyor marketing development model in pandemic era covid 19. The research method uses explanatory sequential methods with a research population of 15 entrepreneurs who understand Kalijambe, Miri, and Plupuh goyor woven fabric products. Data analysis Likert scale using preferences costumers while increasing product marketing uses a participatory approach. The research results showed that goyor fabric product preferred by consumers has the characteristics of using a marketing mix approach as follows: (1) product variables; (2) variable prices; (3) promotion variables; (4) place variables, (5) people, (6) physic, (7) process, (8) public relation and (9) power). The concept of strategy empowerment and market-oriented product marketing empowerment model is said to be feasible and reasonable. It can be used as a marketing development model in increasing interest in buying goyor products in the pandemic era covid 19.
\end{abstract}

Keywords: marketing model, Goyor fabric, buying, interest, covid-19

\section{INTRODUCTION}

Goyor woven fabric is inherited and preserved from generation to generation and accepted by people in the homeland of Indonesia. Goyor tradition in Indonesia is a historical fact that proves the existence of goyor until the present. It is a sturdy foundation for goyor in Indonesia and makes it worthy of being recognized as an Indonesian cultural (Pratiwi, 2019). The development of goyor motifs has been increasingly diverse, adapted to the local area style as the wealth of the archipelago goyor and

\footnotetext{
1 Industrial Engineering Department, Faculty of Engineering, Universitas Muhammadiyah Surakarta, JIn. Ahmad Yani, Pabelan, Kartasura 57162, Indonesia

a email: sur185@ums.ac.id

b email: much.djunaidi@ums.ac.id

- corresponding author
}

Submited: 01-04-2021

Revised: 20-05-2021 as a reflection of the Indonesian identity such as the goyor motif. In Indonesia have moven fabric: Aceh gate and gayo; moven fabric Padang from West Sumatra; Bengkulu; Riau with floral motifs combined with soft shades and perpendicular grooves referred to a veil; Palembang such as Jambi, Java, Kalimantan, Sulawesi, up to Papuan moven fabric (Kina, 2013).

Every province in Indonesia has woven special fabrics according to the region's characteristics, such as Aceh weaving is famous for its sparkling "songket" colors and patterns. Batak weaving in North Sumatra is called "ulos," weaving used for traditional activities, joy, and grieving with neutral colors, black, brown, and not bright (Suranto, 2020).

Minangkabau woven fabric in West Sumatra is popular with "songket" using gold yarn. It is usually used for traditional events, weddings, "pandai sikek" motifs, and "silungkang." Woven fabric in Jambi Province is generally in the form of a "songket." Woven fabric in Riau Province, better known as "songket Siak," Palembang Province's 
woven fabric with Sriwijaya royal motif songket is usually in the form of shoots of bamboo shoots. Lampung Province woven fabric with a filter model that contains motifs typical of the Lampung area.

Woven fabrics in Central Java, located in Jepara with torso weaving, are made from warp and weft yarns previously dipped in natural dyes. Sragen, Sukoharjo, Pemalang, and Pekalongan also have goyor woven fabrics, which combine warp and weft yarns with floral motifs and soft lines of rayon yarn.

Woven fabrics in Solo and Yogyakarta have a strong local shade motif with flora-fauna, dark tapered lines, natural colors, red and green colors. Woven fabric in the East Kalimantan region, with "Doyo" weaving, is in the animal, plant, and mythological patterns dominated by red, brown, and black. With the most famous food weaving, woven fabric in South Kalimantan has become the target of many world designers. West Kalimantan with Sambas songket woven, which is in great demand by Brunei Darussalam, is in a typical orange motif with natural dyes (Sari, 2018).

Utilizing the potential of goyor woven fabric business opportunities requires pro-active steps that are not easy, mainly taking place in the millennia era that is different from the previous era, so it cannot entirely rely on the archaic conventional experience.

Today, goyor woven fabric entrepreneurs have been connected with all of the millennium power. The market, which was once limited by distance and time, has now expanded without the limit of distance and time in selling its products.

Goyor woven fabric originates from Central Java Province and is one of the most famous fabric types because of its convenience, artistic value, and philosophical motifs contained in it. Goyor in Javanese is defined as soft, following the character of Goyor fabric that is not stiff and soft when used (Sari, 2018).

The convenience, traditional nuances, and artistic value of Goyor fabric have made it a high price compared to other materials. Even though Goyor fabric in Indonesia is relatively expensive, it still becomes an excellent fabric, especially for the upper-middle class. Goyor woven fabric products have come through exports to the Middle East region.

Goyor woven fabric has been inherited and preserved from generation to generation and accepted by Indonesian people since the 18th century (Ambarwati, 2013). Goyor weaving fabric motifs are increasingly diverse adapted to the local area style as the archipelago treasure, reflecting the Indonesian people's identity.

The creative industry market, including the creative industry of woven fabric, experienced a significant enhancement in competition between local and national initiatives and various multinational enterprises (Pratiwi, 2020). Indonesia has entered the ASEAN Economic Community (AEC) since the beginning of 2015. Both goods, services, capital, labor from all neighboring ASEAN member countries are free to enter the country. The creative business of Goyor woven fabric is an opportunity for the creative homeland industries to broaden their market level. Still, on the other hand, it can be a threat caused by increasingly fierce competition due to free entry from other countries. Daryono \& Wahyudi (2008) showed that small and mediumsized industries needed the government role and intervention to increase competitiveness, regulations, regulations that favor the small industry in providing credit, improving human resource superiority, quality of products, innovation, and price management.

Based on field observations in three locations at district Kalijambe, Miri, and Plupuh in Goyor Industrial Centers (GIC) Sragen, weaving entrepreneurs still experience difficulties at different levels, including: in terms of human resource management, access to technology, production processes, marketing, promotion, online network and bank access (Setiawati, 2015, Novitasari: 2017). Goyor business needs to increase production capacity to deal with dialectical challenges to take advantage of future dynamics where there are still many other challenges that require pro-active anticipation. The development of goyor weaving work productivity is influenced by labor and capital variables towards production. Based on the research, there are various problems faced by 
goyor woven fabric entrepreneurs in Kalijambe, Miri, and Plupuh Goyor Center, in a pandemic era, covid 19, namely: (a) low consumer buying interest, (b) low market access, (c) low-quality production, (d) strict sales competition, (d) weak sales strategy, (e) lack of social media networks use, (f) retro goyor designs or motifs.

Problems related to technology, human resources, raw materials, and capital (finance) are not crucial problems, but marketing problems have been a priority that goyor woven fabric entrepreneurs must solve in Kalijambe, Miri, and Plupuh Sragen. Therefore, we need the synergy role of goyor entrepreneurs, cooperatives, and policymakers in the local area.

Based on the reality that occurs in the field, it is expected that the role of assistance through the suitable empowerment model provides input and contribution in helping to solve marketing problems dealt by goyor woven fabric entrepreneurs. Marketing development through empowerment is a continuous learning process that aims to give strength to the community so that: (I) they have awareness, confidence, and firmness in all aspects of life; (2) they can make decisions, solve the problems, and be creative in small businesses; (3) they can cooperate and foster relationships in the business environment and social environment; and (4) they can access resources, information, opportunities, knowledge, and skills for business continuity and family life for a better future life.

Regarding functional strategy, marketing development for goyor entrepreneurs in Kalijambe Sragen can be implemented using a practical economic approach, such as the marketing mix of goyor products.

Based on the functional strategy approach, the marketing development of goyor woven fabric entrepreneurs can be shown by the ability to access the market widely. Small businesses will be more competitive in the market through the right marketing mix (product, price, promotion, place, people, physic, process, public relation, and power). Marketing mix can be optimal if goyor woven fabric entrepreneurs have the awareness to be organized to go through more expansive marketing areas. Going through the market collectively is relatively more accessible than the single fighter pattern (individual struggle). For small businesses, effectiveness and efficiency cannot be forced but can only be stimulated. Efficiency in production and marketing processes is the result of continuous development efforts (Pratiwi, 2020), (Arsita, 2020), (Syarifah, 2017).

Based on the support of the results of the study, the marketing mix variables (product, price, promotion, and distribution) affect consumers' buying interest and need: (1) an identification of product attributes as consumer's desire, (2) to figure out the marketing development model of goyor woven fabric entrepreneurs based on the market-oriented to increase the consumer buying interest, so that it can be used to assist regarding product standardization, price, promotion and distribution, people, physic, process, public relation and power as consumers' desire (Astuti, 2015; Pater, 2018).

\section{RESEARCH METHOD}

The research paradigm uses observational analytics, a quantitative study to understand the preferences costumer the marketing mix with consumer buying interest. Quantitative studies use preferences costumer with Likert of scala analysis, the aim of understanding how respondents develop their desires or interests in a product (goyor woven fabric) and use strategic analysis to analyze the model marketing mix factors (product standardization, price, promotion, and distribution, people, physic, process, public relation and power as consumers' desire).

The research design was observational analytic using mixed methods, which combined quantitative and qualitative methods. Quantitative methods as the main study, while qualitative methods as the support method. The researchers examine the strategy marketing mix variables (product standardization, price, promotion and distribution, people, physic, process, public relation, and power as consumers) and buying interest variables.

The population in this study were consumers (buyers) of Kalijambe, Miri, Plupuh Sragen of 
Goyor. Participants who participated in the sample were chosen accidentally, accidental sampling (Ferdinand, 2010).

Sample in this study was a number of Kalijambe, Miri, Plupuh Sragen goyor buyers. In this study, a sample of 100 consumers bought Kalijambe, Miri, Plupuh goyor. Based on the central limit theorem (central limit theorem), it is said that large pieces will follow the normal distribution, even though the population from which the samples were obtained did not have a normal distribution. Since the sample data is large (100 consumers), the sample data follows the normal distribution.

Data collection techniques in this study were carried out using: (1) questionnaire, (2) observation, (3) documentation (literature study). Data analysis techniques used in this study are (1) descriptive analysis through a questionnaire to explore the sources of respondents, (2) validity and reliability analysis of the questionnaire, (3) Scala Likert Analysis, through a questionnaire to explore the consumers' interests (preferences) of Kalijambe, Miri, Plupuh Goyor attributes, (4) Strategy analysis, through a questionnaire to determine the marketing mix variables and consumer buying interest in market-oriented goyor woven fabric products.

\section{RESULT AND DisCUSSION}

Recapitulation of Goyor Moven Fabric Attributes Desired by Consumers

Based on the Scala Likert analysis results, it is obtained that the result recapitulation of respondents as many as 100 consumers and the results are as shown in example Table 1.

Table 1 evaluates the recognized attributes of consumer buying interest: First, seen from the attributes of Kalijambe, Miri, Plupuh Sragen goyor products with the following criteria: (1) type of fabric made from rayon woven fabric; (2) pattern/motif product: goyor botolan; (3) reliability product is first washed not fade; (4) fabric size: $70 \mathrm{~cm}$ x $180 \mathrm{~cm}$; (5) color product is red; (6) merk product: as order; (7) quality product good quality and affordable price.

Second, seen from the price attributes,
Goyor Kalijambe, Miri, Plupuh Sragen has the following criteria: (1) prices between Rp. 200,000 up to Rp. 250,000 per piece; (2) giving discounts/discounts offered at the event and during the promo; (3) lower prices than similar products sold in the market.

Third, seen from the promotion attributes, goyor entrepreneur Kalijambe Sragen must carry out activities: (1) make advertisements on social media/internet, and also making a signboard; (2) sold in stores/boutiques and also uses marketing personnel; (3) actively follow the events; (4) sometimes carry out CSR; Indonesian people widely know (5) advertising objectives.

Fourth, seen from the distribution attributes, Kalijambe, Miri, Plupuh Sragen goyor entrepreneurs must strive to (1) The location of the good, needs to be sold in every store in all regencies/cities in Indonesia; (2) delivery of goods to the customer's address suitable with the promised time; (3) Kalijambe, Miri, Plupuh Sragen goyor products are also sold through online stores; and products are sold in stores/outlets outside Sragen.

Fifth, seen from the people attributes, (1) Performance skill, proficient and skillful, (2) Attitude, needs friendly and polite behavior, (3) Knowledge need ability is outstanding. Sixth, seen from the physic attributes, (1) Lightning system, need Attractive design, (2) software accounting need very needed, (3) exciting building need fun design. Seventh, seen from the process attributes, (1) making process need very needed, (2) delivery process, need accuracy skill, and (3) service process needs excellent skill. Eight, seen from the public relation attributes, (1) people's opinion needs very important, (2) share experience need essential.

Ninth, seen from the power as consumers attributes, (1) business policy needs very. important, (2) government participants need a mature forecast. Based on the analysis results of correlation among the marketing mix variable and consumer buying interest described above, the marketing model for goyor woven fabric entrepreneurs is quite good and can be carried out follows. 
Table 1. Sragen Kalijambe, Miri, Plupuh Desired by Consumers

\begin{tabular}{|c|c|c|c|}
\hline No. & Dimension & Criteria & $\%$ \\
\hline \multicolumn{4}{|c|}{ Product } \\
\hline 1 & Types of fabric product & Rayon & 84 \\
\hline 2 & Motif product & Goyor botolan & 76 \\
\hline 3 & Reliability product & Fist washed not fade & 96 \\
\hline 4 & Spesification/fabric size & $70 \mathrm{~cm} \times 180 \mathrm{~cm}$ & 54 \\
\hline 5 & Colour product & Red & 57 \\
\hline 6 & Merk product & As order & 86 \\
\hline 7 & Quality product & Good but affordable & 74 \\
\hline \multicolumn{4}{|c|}{ Price } \\
\hline 1 & The price consumer & Rp 200.000-250.000/pcs & 87 \\
\hline 2 & Discount & Given every purchase and during the promo & 89 \\
\hline 3 & Competitor & Don't compete & 95 \\
\hline \multicolumn{4}{|c|}{ Promotion } \\
\hline 1 & Advertising & Social media and the internet, as well as creating a signboard & 83 \\
\hline 2 & Personal Selling & Sold in stores/galleries, and also use marketing personnel & 76 \\
\hline 3 & Sales promotion & Active in events & 89 \\
\hline 4 & Publicity & Active in CSR & 72 \\
\hline 5 & Popularity & Known to Indonesian society & 70 \\
\hline \multicolumn{4}{|c|}{ Place/ Distribution } \\
\hline 1 & The location of the good & Sold in stores throughout the city/district in Indonesia & 58 \\
\hline 2 & On-time delivery & According to the promised time & 89 \\
\hline 3 & Product search speed & Sold through social media / online internet promotion & 92 \\
\hline \multicolumn{4}{|c|}{ People } \\
\hline 1 & Performance skill & proficient and skillful & 65 \\
\hline 2 & Attitude & friendly and polite behavior & 89 \\
\hline 3 & Knowledge & ability is very good & 93 \\
\hline \multicolumn{4}{|c|}{ Physic } \\
\hline 1 & Lightning system & Attractive design & 87 \\
\hline 2 & Software accounting & Very needed & 90 \\
\hline 3 & Interesting building & Fun design & 92 \\
\hline \multicolumn{4}{|c|}{ Process } \\
\hline 1 & Making process & Very needed & 67 \\
\hline 2 & Delivery process & Accuracy skill & 84 \\
\hline 3 & Service process & Excellent service & 74 \\
\hline \multicolumn{4}{|c|}{ Public relation } \\
\hline 1 & People opinion & Very important & 69 \\
\hline 2 & Share experience & Important & 87 \\
\hline \multicolumn{4}{|c|}{ Power as consumers } \\
\hline 1 & Business policy & Very important & 91 \\
\hline 2 & $\begin{array}{l}\text { Government } \\
\text { participation }\end{array}$ & Mature forecast & 78 \\
\hline
\end{tabular}

Source: Summary of data processing results of SPSS 22.0

\section{Production Strategy}

Empowerment strategies for goyor woven fabric entrepreneurs Kalijambe, Miri, Plupuh Sragen to increase the consumer buying interest and the volume of goyor woven fabric sales can be carried out using a functional strategy: (1) Functional economic strategy, which includes functions that enable organizations to live as a healthy economic unit, including those that are related to finance, marketing, resources, research, and development; (2) Functional management strategies, including the functions of planning, organizing, implementing, controlling staffing, leading, motivating, communicating, decision making, representing and integrating; (3) Strategic issue strategy, its primary function is to control the environment, either known environmental situation, unknown environmental situation, or changing environmental situation (Pratiwi, 2020). 
Related to functional strategy, empowerment of goyor move fabric entrepreneurs in Kalijambe Sragen can be carried out using a practical economic approach, such as the marketing mix of goyor products. Functional management strategies that can be carried out are increasing managerial capacity (managing organizations/ businesses) for goyor woven fabric makers and strategic issue strategies that can be carried out by understanding goyor woven fabric entrepreneurs about market conditions and needs consumer buying interest.

Entrepreneur empowerment is shown by building competitiveness by growing awareness of small entrepreneurs about quality, service, environment, organization, harmony, cooperation, honesty, and other things that influence the marketing with a broader market reach. The process of changing the mindset, from an inward orientation to an outward direction, is needed so that small business groups can accurately anticipate changes in the business climate, especially changes in competition patterns.

Empowerment is demonstrated by the ability to access the market widely. Through the right marketing mix strategy, small businesses will be more competitive in the market. Marketing mix can be optimal if small companies can organize to go through the wider marketing area. It is usually easier breaking into the market collectively than a single fighter pattern (Pratiwi, 2016).

\section{Products}

Kalijambe, Miri, Plupuh Sragen goyor woven fabric products that are in desire by consumers are: (1) type of fabric made from rayon woven fabric; (2) pattern/motif product: goyor botolan; (3) reliability product is first washed not fade; (4) fabric size: $70 \mathrm{~cm} \times 180 \mathrm{~cm}$; (5) color product is red; (6) merk product: as order; (7) quality product good quality and affordable price.

Related to the above criteria, the goyor woven fabric entrepreneur Kalijambe, Miri, Plupuh Sragen must pay attention and be able to realize the consumers' desires if they want to have their business becomes exist and competitive with other goyor productions. Based on an interview with head entrepreneur Kalijambe, Miri, Plupuh
Sragen, it said that: Most of Kalijambe, Miri, Plupuh goyor woven fabric products are good quality, especially products which are produced by entrepreneurs who have long, experienced and classified as established entrepreneurs. However, for small and not yet well-established entrepreneurs, the quality of their products is sometimes still not good. Empowerment is already run, mainly to improve product quality, and for others, it is still not sufficient.

\section{Promotion}

Seen from the promotion attributes, goyor consumers want Kalijambe, Miri, Plupuh Sragen goyor woven fabric entrepreneurs to carry out activities, such as: (1) make advertisements on social media/internet, and also making a signboard; (2) sold in stores/boutiques and also uses marketing personnel; (3) actively follow the events; (4) sometimes carry out CSR; Indonesian people widely know (5) advertising objectives.

Promotion will direct consumers to buy products that producers have designed to fulfill consumer needs and provide a level of satisfaction to consumers. Through promotional activities, it is hoped to be able to attract the consumers' attention to buy products as well as being able to provide strong buyer responses and boost sales in the short term. Promotion plays a role in promoting good information delivery to consumers about the benefits or advantages of a product to affect the consumer's mind and raise interest to buy the product.

Based on an interview with head entrepreneur goyor woven fabric in Kalijambe, Miri, Plupuh Sragen, it is said that: "our product sales are still substandard, we do not have marketing personnel, we have not put on the signboard, and we do not use social media for promotion."

\section{Price}

Seen from the price, Kalijambe, Miri, Plupuh Sragen goyor woven fabric consumers want price, as follows: (1) prices between Rp200,000 up to Rp250,000 per piece; (2) giving discounts/discounts given at the time of the event and during the promo; (3) lower prices than 
similar products sold in the market.

Price plays a strategic role in marketing, and if the price is too high, then the product will not be affordable to the target market. Consumer buying interest tends to decrease towards the product because a consumer considers its quality and thinks of the price feasibility in buying a product. Price is one of the determinants of product selection that will affect buying interest. Based on an interview with head entrepreneur goyor woven fabric in Kalijambe Sragen, it is said that: "Our goyor is sold at a price of between Rp200,000 up to Rp250,000 per pcs. The price depends on the motif, material, and size of the fabric".

\section{Place or Distribution}

Seen from the distribution attributes, Kalijambe, Miri, Plupuh goyor woven fabric entrepreneur must strive to do several things, such as (1) The location of the good, needs to be sold in every store in all regencies/cities in Indonesia; (2) delivery of goods to the customer's address suitable with the promised time; (3) Kalijambe, Miri, Plupuh Sragen goyor products are also sold through online stores; and products are sold in stores/outlets outside Sragen. Based on an interview with head entrepreneur goyor Kalijambe, Miri, Plupuh, it is said that: "we only sell goyor woven fabric at home, and do not have a store or showroom." Then, based on an interview, it is said that "we sell goyor only at home, and have not had a store yet."

\section{People}

Seen from the people attributes, (1) Performance skill, proficient and skillful, (2) attitude, needs friendly and polite behavior, (3) knowledge need ability is very good. Public opinion is very important to be considered and built. Building public opinion is not easy. Before building public opinion about the company's products, the company must maximize some of the aspects above.

\section{Physic}

Seen from the physic attributes, Lightning system, need Attractive design, software accounting need very needed, (3) interesting building need fun design. The physical appearance includes how the place of business looks, product appearance, the appearance of the waiters, and other supporting designs. This aspect is crucial to note in the marketing mix because a good view is the first step for consumers to come and try the products offered. The better the overall design appearance, the more consumer attention.

\section{Process}

Seen from the process attributes, (1) making the process very needed, (2) delivery process, need accuracy skill, and (3) service process needs excellent skill. Companies produce products and provide services to consumers so that they are satisfied with what the company offers. Companies must be sensitive to creativity and innovation to deliver the best products with excellent service to consumers.

\section{Public Relation}

Seen from the public relation attributes, (1) people's opinion need very important, (2) share experience need essential. The current marketing mix concept, public opinion, is very important to be considered and developed. Building public opinion is not easy. Before making a general opinion about the company's products, the company must maximize some of the aspects above.

\section{Power as Consumer}

Seen from the power as consumers attributes, (1) business policy needs very important, (2) government participant needs a mature forecast. the company's ability to participate in national and international politics has an important influence on the sustainability of a business. In general, this aspect is often considered by large-scale companies that are closely related to government policies (Pratiwi, 2020)

\section{Marketing and Empowerment Technique}

Empowerment techniques for goyor woven (2) fabric entrepreneurs Kalijambe, Miri, Plupuh 
Sragen can be done through assistance, counseling, and services. As explained, community empowerment is the embodiment of community capacity building nuanced in empowering human resources through institutional development, starting from the central level to the rural level. The empowerment target for goyor woven fabric entrepreneurs Kalijambe, Miri, and Plupuh Sragen can be classified into two groups: personal and institutional.

Personal empowerment aims to improve every goyor entrepreneur's skills, which aims to develop the potential of goyor entrepreneurs in Kalijambe, Miri, Plupuh Sragen. This personal empowerment is conducted to improve the knowledge, skills, attitudes, self-awareness of goyor entrepreneurs.

Institutional empowerment is aimed to enhance the institutional or organizational capacity of Kalijambe, Miri, Plupuh Sragen goyor entrepreneurs. This institutional empowerment needs to be conducted because there are problems encountered by goyor entrepreneurs who need collaborative problem solutions (together) and cannot be solved personally (individually).

Problems in pandemic era covid 19 that need to be solved together include: (1) Desire for large-scale goyor products from business partners that goyor entrepreneurs themselves cannot do; (2) Implementation of promotions that can improve the image of Kalijambe, Miri, Plupuh goyor and a broad marketing network that cannot only be done individually; (3) Determination of the standard selling price of goyor that can avoid the problem of unfair competition that can harm goyor entrepreneurs in the vicinity; (4) Provision of central goyor distribution that can accommodate various goyor productions of Kalijambe, Miri, Plupuh Sragen goyor entrepreneurs.

\section{CONCLUSION}

Consumer buying interest which is based on the attributes of goyor Industrial Goyor Center (IGC) in Kalijambe, Miri, Plupuh Sragen district and seen from the conjoint analysis is as follows: (a) product: (1) type of fabric made from rayon woven fabric; (2) pattern/motif product: goyor botolan; (3) reliability product is first washed not fade; (4) fabric size: $70 \mathrm{~cm}$ x $180 \mathrm{~cm}$; (5) color product is red; (6) merk product: as order; (7) quality product good quality and affordable price.; (b) promotion: (1) make advertisements on social media/internet, and also making a signboard; (2) sold in stores/boutiques and also uses marketing personnel; (3) actively follow the events; (4) sometimes carry out CSR; (5) advertising objectives are widely known by Indonesian people; (c) (1) prices between Rp. 200,000 up to Rp. Two hundred fifty thousand per piece; (2) giving discounts/discounts offered at the time of the event and during the promo; (3) lower prices than similar products sold in the market; (d) (1) The location of the suitable needs to be sold in every store in all regencies/cities in Indonesia; (2) delivery of goods to the customer's address suitable with the promised time; (3) Kalijambe, Miri, Plupuh (CIG) Sragen goyor products are also sold through online stores; and products are sold in stores/outlets outside Sragen, (e) the people attributes, (1) Performance skill, proficient and skillful, (2) attitude, needs friendly and polite behavior, (3) knowledge need ability is very good. (f) the physic attributes, (1) Lightning system, need Attractive design, (2) software accounting need very needed, (3) exciting building need fun design. ( $\mathrm{g}$ ) the process attributes, (1) making process need very needed, (2) delivery process, need accuracy skill, and (3) service process needs excellent skill. (h) the public relation attributes, (1) people's opinion need very important, (2) share experience need essential. (i) the power as consumers attributes, (1) business policy needs essential, (2) government participant need a mature forecast.

Marketing development and empowerment model that can be done for goyor entrepreneurs based on market-oriented marketing that can increase consumer buying interest are as follows: (a) Empowerment Strategy, Empowerment strategies for goyor entrepreneurs Kalijambe Sragen to increase consumer buying interest and the volume of goyor woven fabric sales can be 
done with a functional strategy by using an economic functional approach, such as the marketing mix of goyor products. Available management strategies can be done by increasing managerial capacity (managing organizations/businesses) for goyor makers, and strategic issues strategies can be done through understanding goyor entrepreneurs about market conditions and needs, such as consumer buying interest; (b) Empowerment Techniques, the empowerment technique for goyor entrepreneurs Kalijambe Sragen can be done through assistance, counseling, and service.

Mentoring can motivate the participation of CIG (Kalijambe, Miri, Plupuh) Sragen goyor entrepreneurs because the facilitation is oriented to dialogue relations, problems correlation that discuss entrepreneurship in the context of increasing the empowerment of CIG (Kalijambe, Miri, Plupuh) Sragen goyor entrepreneurs; (c) Empowerment Target, The empowerment target for goyor entrepreneurs Kelijambe Sragen can be classified into two groups, namely personal and institutional.

Personal empowerment is intended to improve the skills of every goyor entrepreneur, which aims to develop the potential of goyor entrepreneurs in Central Industry Goyor (CIG) Kalijambe, Miri, Plupuh Sragen.

\section{REFERENCES}

Ambarwati. M. (2013)." Study of Mr Sudarto's Goyor Woven Fabric Craft in Kenteng Village Tawangsari Sukoharjo". FKIP Journal. Vol 03. No 2. UNS. Surakarta.

Arsita. M., A. Zubeir, A. Demartoto. (2020). "Keterlekatan Sosial UMKM Sarung Tenun Goyor di Desa Sambirembe Kalijambe Sragen". Society. Journal. vol. 8, no. 3, 381-389., doi: 10.33019/society.v8i2.198

Astuti, R. L. R. Silalahi, G. D. P. Wijaya. (2015). "Marketing Strategy Based on Marketing Mix Influence on Purchasing Decisions of Malang Apples Consumers at Giant Olympic Garden Mall (MOG), Malang City, East Java Province, Indonesia," Agric. Agric. Sci. Procedia, vol. 3, pp. 67-71, doi: 10.1016/j.aaspro.2015.01.015.

Bukhori. A. (2016). "Kewirausahaan. Bandung": Alfabeta. Bandung: Alfa Beta, Bandung, 2016
Creswell. (2012). "Mixed Methods Research in Sports Marketing." International Journal of Multiple Research Approaches. Vol 09. September.

Daryono., Wahyudi. (2008). "Competency Analysis of Regional Competitive Products in Goyor Solo and Cap in the Second Region of Surakarta City." Journal of Economic Development, 9 (2):pp: 184 197.

Ferdinand. A. (2010). "Marketing Management: A Strategic Approach". Semarang: Badan Penerbit Universitas Diponegoro.

Kina. (2013). Pusat Komunikasi Publik. Kementrian Perindustrian. Jakarta

Novitasari A.T. (2017). "The Effect of Working Capital, Labor Skills, and Innovation on the Growth of Goyor Small Businesses in Tanjung Bumi District, Bangkalan District". Eco-Socio: Jurnal Ilmu dan Pendidikan Ekonomi-Sosial, Vol: 1. ISSN: 2597-7806.

Pater. L. R and S. L. Cristea. (2018). "A Systemic Characterization of Organizational Marketing," Procedia - Soc. Behav. Sci., vol. 238, pp. 414-423, doi: 10.1016/j.sbspro.2018.04.019.

Pratiwi. A. I. W. Utami. S .Ilham. (2019). "Marketing Strategy of Market Oriented Batik". Prosiding. Internasional Conference.Vol 1 No 1. Universitas Duta Bangsa. Surakarta. Pp: 23-34.

Pratiwi. A., A. L. Riani., M. Harisudin., S. R.H. Pinta. (2020). "The Management Model Of Batik Production In Pandemic Era Covid 19 (A Study At The Industrial Center Of Batik Masaran Sragen Indonesia)". ISSN: 04532198 Volume 62, Issue 10, November,. Journal of TRKU. Japan

Pratiwi.A., A. L. Riani., M. Harisudin., S. R.H. Pinta. (2016). "Empowerment of Entrepreneur Batik in Masaran Sragen". Journal of Scientific and Engineering Research Vol 03, No 06.pp: 234-245. India

Pratiwi.A., A. L. Riani., M. Harisudin., S. R.H. Pinta. (2020). "Marketing Model For Creative Industry Goyor Market Oriented In The Industrial Era 4.0 (Case Study Goyor Creative Industry Center, Sragen, Indonesia)". Jurnal TRKU Japan. ISSN: 04532198 Volume 62, Issue 10, November.

Sari, A.,W., R. Kardoyo., (2018). "Total Production of Goyor Sarong Weaving: Estimated from Labor, Capital and Entrepreneurship Capability." Economic Education Analysis Journal. Vol 07, 01.

Setiawati E., Nursiam, Zulfikar. (2015). "Development of Batik Commodities: Determination of Economic Culture and Changes in Policy Structure of the Development of Local Economic Enterprises (Study of Batik Laweyan Entrepreneurs in Surakarta)." Economic and Business Journal, Vol: XVIII. ISSN: $1979-6471$ 
Suranto.,Pratiwi.A. (2020). "Model Pengembangan Pemasaran Kain Tenun Goyor Berorientasi Pasar Berdasar Keinginan Konsumen di Era Industri 4.0 (Sentra Industri Kain Goyor Sragen Indonesia)". Seminar IENACO VIII Teknik Industri UMS. 18 Maret 2020.

Syarifah. H, A. Nalau.,M. Wasi. (2017). "Brand Image Terhadap Loyalitas Pelanggan J.co Donut \& Coffe di Plaza Mulia," J. Ekon., vol. 2, no. 4, pp. 89-100. 